Original Research Paper

\title{
Transportation Engineering
}

\author{
${ }^{1}$ Relly Victoria V. Petrescu, ${ }^{2}$ Raffaella Aversa, \\ ${ }^{2}$ Antonio Apicella and ${ }^{1}$ Florian Ion T. Petrescu \\ ${ }^{1}$ ARoTMM-IFToMM, Bucharest Polytechnic University, Bucharest, (CE), Romania \\ ${ }^{2}$ Advanced Material Lab, Department of Architecture and Industrial Design, \\ Second University of Naples, 81031 Aversa (CE), Italy
}

\author{
Article history \\ Received: 06-07-2017 \\ Revised: 13-07-2017 \\ Accepted: 13-07-2017 \\ Corresponding Author: \\ Florian Ion Tiberiu Petrescu \\ IFToMM, ARoTMM, \\ Bucharest Polytechnic \\ University, Bucharest, \\ Romania \\ Email: scipub02@gmail.com
}

\begin{abstract}
The shipments were absolutely necessary at all times, but still have polluted and damaged the environment. The technique of transport or the engineering of transport is the application of the principles of technology and scientific findings to the planning, design check, operation and plan management for any mode of transport, in order to ensure that the conditions of safety, efficiency, quick, comfortable and convenient, economic and environmentally compatible movement of persons and goods (transport). It is a sub-discipline for civil engineering. The importance of the transport engineering in the framework of the profession of civil engineering can be evaluated by the number of divisions of the American Society of Civil Engineers (ASCE), which are directly related to the transport. There are six such divisions (Aerospace; Air Transport, motorways, pipes, watercourses, port, of coastal and ocean and urban transport), which represents one third of the total 18 technical divisions of the ASCE (1987). Humanity is struggling between technological tests of deployment of new types of mild transport for the environment and the need to maintain still in the operation the machines already polluting products in large quantity, cheaper, more convenient economically, that customers have already been accustomed. Transport is at the heart of major cross-cutting issues that are inseparable from issues related to the development and sustainable management of the mobility of goods and people. The automotive sector must meet several challenges to reduce the emission of particulate and gaseous pollutants while limiting the increase in the cost of vehicles. The development of "clean" or "sustainable" vehicles requires the integration of innovative technologies to meet all these requirements. Those all problems need to be addressed by the discipline named Transportation (Transport) Engineering, in view of the constantly improving the quality of transport carried out.
\end{abstract}

Keywords: Transport Engineering, Civil Engineering, Quality Transport, Modern Transport, Friendly Environmental Transport, Sustainable Transport, Flexible Transport

\section{Introduction}

Transport engineering is a branch of industrial engineering applied to the creation of means of transport (Barrett and Odum, 2000).

Automotive design is divided (often subdivided into interior design and exterior automotive design), railway design, aeronautics, etc.

Designers in the field of transport can work for manufacturers and equipment makers (integrated designers), for agencies that can subcontract all or part of the work expected by manufacturers, or be consulted as independent designers (Sethusundaram et al., 2013).

For certain manufacturers (ex: PSA) the French name "stylists" is used more to designate designers. Overseas the term "designer" is always confusing, especially in the fields where designers are rare: e.g., "naval designer" will more often designate a naval architect than a stylist specialized in the field of sailing. 
The designers (or stylists) specialized in transport all work in close collaboration with the actors of the commercial parties (Marketing, Product, sales, after sales ...) and technical (technicians, ergonomists, engineers ...) question.

One can talk today about some important transport branches:

- Vehicles and mobility of the future

- Rail systems

- Aeronautical systems

- Transport of river and maritime

- Aerospace

- Special vehicles

- $\quad$ Special transportations (pipes,...)

Transport is at the heart of major cross-cutting issues that are inseparable from issues related to the development and sustainable management of the mobility of goods and people.

The automotive sector must meet several challenges to reduce the emission of particulate and gaseous pollutants while limiting the increase in the cost of vehicles. The development of "clean" or "sustainable" vehicles requires the integration of innovative technologies to meet all these requirements.

Thirty years ago, the concept of sustainable development was widely known and accepted; It proposes to reconcile economic development, satisfy the essential needs of the populations and preserve the environment (Aversa et al., 2016a; 2016b; 2016c).

For example, the environmental aspect of this concept may be applied to the field of freight transport.

The first step is to better understand the link between transport activities and environmental degradation by drawing up an inventory of the various environmental impacts such as the increase in the greenhouse effect, atmospheric pollution and noise: Are these impacts in the case of freight transport? To describe the energy and environmental performance of transport, it will be necessary to distinguish the different transport solutions (mode, vehicle) and the operational parameters (speed, loading rate). Beyond this, attention will have to be paid to the challenges posed by the design of logistics chains and logistical practices: Logistics schemes and organizations determine the flow of goods and thus strongly influence the environmental performance of transporting a product and its raw materials. The varied work carried out in recent years, be it national statistics, studies, research and calculation tools, now provide essential information.

Stakeholders in the industry, whether they are carriers, freight forwarders or shippers, are now moving in a relatively clear context, which should encourage them to demonstrate their commitment. Structural action programs such as charters of voluntary commitments are being developed or under development to promote and facilitate such commitments and it is particularly useful to take note of them (Ronney et al., 1994).

Fossil fuels have provided humanity with cheap, concentrated energy that has made it possible for the majority of the population to attain a standard of living that has never been equaled in the past. These fossil riches are however finished and their massive use rejects carbon dioxide $\left(\mathrm{CO}_{2}\right)$ which contributes to increase the greenhouse effect with negative implications for the climate.

Today, humanity is facing an energy challenge to reduce its $\mathrm{CO}_{2}$ emissions on the one hand and gradually to replace fossil fuels with other sources of energy that do not emit gas.

To meet this challenge, we will have to increase the contribution of clean energy (renewable and nuclear) but above all to be more sober and use energy more efficiently.

Transport of any type can't be thought today without taking into account the problems of the environment. Energy is essential to economic development. Modern civilizations have developed over the last two centuries thanks to the fossil fuels that have made it possible to have concentrated and inexpensive sources of energy (Petrescu et al., 2016a; 2016b; Petrescu and Calautit, 2016).

They cover about $80 \%$ of the world's energy needs but are in finite quantity. In addition, the use of fossil fuels rejects carbon dioxide, which increases the greenhouse effect.

The energy challenge facing humankind today in the energy field is to reduce $\mathrm{CO}_{2}$ emissions and, gradually, to substitute fossil fuels with other sources of energy that do not emit carbon dioxide $\left(\mathrm{CO}_{2}\right)$.

To meet this challenge, it is necessary to save energy, to use more efficient devices and to use carbon-free (renewable and nuclear) energy sources on a large scale (Cauvin, 1994; Dupuy, 1991; Feldman, 2008; Gallez et al., 1997; Genre-Grandpierre, 2000; 2007; Gutiérrez et al., 1998; Leet et al., 2004; Madre and Maffre, 1997; Mahalingam and Ramesh, 2013; Naima and Liazid, 2013).

The main uses of energy are, in descending order of consumption, the production of thermal energy, transport and electricity.

Electricity is produced worldwide, mostly with coal, but this energy vector can nevertheless be generated virtually from all sources of energy, including carbon-free sources. Transport, on the other hand, depends almost entirely on oil. As far as heat or cold is concerned, fossil fuels could in the future be replaced in the future.

Energy storage is the weak point of the energy sector and major progress remains to be made in this area, 
which is particularly essential for exploiting intermittent energy sources.

Habitat and transportation consume much of the world's energy. Significant gains in energy are possible in the habitat (Thevenin, 2002).

On the other hand, for transportation, the problem is more difficult. Hydrogen, an energy vector on which many bet on short-term transport, will be especially useful for the manufacture of liquid fuels and petrochemicals. It should also be noted that the amount of energy that a source can deliver is not the only important parameter and that in some industrial applications it is sometimes also necessary to have high power levels. Continuous high powers that many renewable sources are incapable provide.

In the field of freight transport, heavy goods vehicles are currently the central link, since they transport the vast majority of goods that meet our needs, thus making our economy live.

Despite lower energy performance than the heavy modes of railways and inland waterways, these vehicles have become established thanks to their flexibility, speed and, ultimately, their profitability.

As a result, the contribution of trucks to greenhouse gas and pollutant emissions is high, with, as a corollary, a dangerous link between our economy and a single resource: Oil.

Given the constraints, the expected progress must be on both: Pollutant emissions and fuel consumption, associated GHG emissions and energy diversification, while maintaining favorable economic equations.

It should also be emphasized that the important links between these parameters are:

- Reducing pollutant emissions generally causes fuel overconsumption by the necessary engine adjustments and the induced masses of the systems

- Reducing consumption opens opportunities for certain sectors, in particular gaseous ones, improves economic balances and can therefore introduce new technological solutions on the vehicle

Note that there is a link between the emissions of NOx and the consumption, which is adjusted by the manufacturer, in particular by the advance to the injection: Reducing NOx leads to an overconsumption of fuel and vice versa. In addition, the equipment in the depollution system (catalyst, filter) leads to increase the mass of vehicle.

Let's think for a moment only to used tires in one year only in France for example.

Aliapur is the main collective organization responsible for recovering used tires in France, which accounts for almost $75 \%$ of the annual deposit, i.e., around 300000 tonnes.
As in the case of all sectors created by the implementation of the principle of extended Producer Responsibility (PWR), Aliapur's primary objective is to ensure the collection of used tires, their sorting and recycling on behalf of their customers respect for the environment, in order to neutralize the environmental risk that can constitute used tires in France.

But the ambitions of the eco-organism go beyond strict compliance with regulatory obligations. Since its inception, Aliapur's aim has been to promote the emergence of an industrial economy structured and creating environmental, economic and societal value around the many Potentialities offered by Used Nonreusable tires (PUNR): Calorific value, carbon and steel, rubber from biomass, etc.

Aliapur's first years of existence were devoted to the professionalization of the sector through the dissemination and consolidation of best practices and know-how, the creation of recognized methods (sampling and characterization) and the definition of values; thus making it possible to offer products that are secured and adapted to the needs of the users.

The eco-organism has also endeavored to seek new ways of valorization with the objective of ensuring the permanent existence of sufficient outlets and allowing management flexibility.

In terms of human health and the environment, important research programs have been devoted to the assessment of environmental risks and health risks as well as environmental assessments based on the methodology of the cycle analyzes of life (LCA).

Shipments were born on the water and have increased by railway, but gained momentum only through the road vehicles and today have moved already in the air or in underground.

To achieve all these transports annually in the world, are consuming massive amounts of fossil fuels, oils for lubrication, tire manufactured all from petroleum, plastics and rubber-upholstery all manufactured in general from petroleum products. Not to mention the immense made pollution, that spills over people like a scourge difficult to be stopped.

Mankind rushes and needs to be transported continuously in various locations, as quickly and better; the same thing for the goods, which becoming more and more diverse (Petrescu, 2012).

We need to transport various goods, fast, in large quantities over long distances, a difficult route.

It comes immediately to a modal transport, which consist in that changing goods from cargo truck on the train, then on boat or plane and after on the truck again. Goods are placed in containers, standardized, easily transferable from one means of transport to another.

Traffic lights must have the green light for rapid transport through the cities.

Train sets must be formed quickly, so as not to delay the transport of perishable goods. 
Transfer of goods is fast with powerful cranes, stable and dynamic.

Ships are not allowed to circumvent and must use a direct route.

Planes huge cargo can fly even faster, almost any weather, at very high altitudes, avoiding any clash in the air, but it requires an army of people to program their routes and to supervise them permanently.

Noise from the transport vehicles should be limited permanently.

All these problems mentioned above and many others must be considered by the specialists in transport engineering, considering permanently increase the quality of transport and to not affect the environment.

\section{Vehicles and Mobility of the Future}

As mentioned already struggling to protect the environment requires more stringent rules permanent to current road vehicles.

By ongoing technological improvements of thermal engines and mechanical transmissions have brought some increases of yield and the rest came through the solving auto pollution by rules and regulations that generally lead to a higher consumption of fossil fuels.

Diesel engines compared to gasoline, due to the specific combustion air-fuel mixture, are producing higher emissions of nitrogen oxides and particulates.

These emissions are harmful to the environment and human.

Pollution standards aim to reduce vehicle pollutant emissions. In European Union, Euro 6 came into force in January 2015 for the new car models (Fig. 1).

An important feature of Euro 6 diesel cars is to reduce NOx limit from 0.18 to $0.08 \mathrm{~g} / \mathrm{km}$. To meet this time current automotive diesel engines require additional after treatment systems exhaust. There are identified two technologies that can be applied to Euro 6 diesel engines:

- $\quad$ catalyst/NOx filter (en: NOx trap)

- The injection system of urea in the exhaust pipe (AdBlue)

The first method, the NOx catalyst, generally applies to small displacement diesel engines and medium cylinder capacity of less than 2 liters. Next, we will discuss urea injection system in the exhaust stream (AdBlue). This system can be used in any diesel engine, but is more expensive, it lends itself more to large displacement engines. Note that this technology is already used in automotive transport.

The reduction of nitrogen oxides in the exhaust gas using a urea-based solution, called selective catalytic reduction. Name devoted to AdBlue injection system is SCR - Selective Reduction Catalityc (Fig. 2).

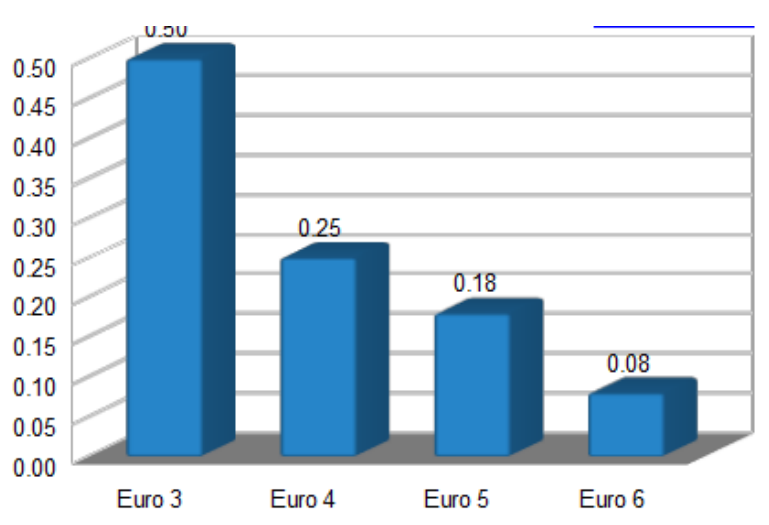

Fig. 1. NOx emission limit for diesel cars $(\mathrm{g} / \mathrm{km})$

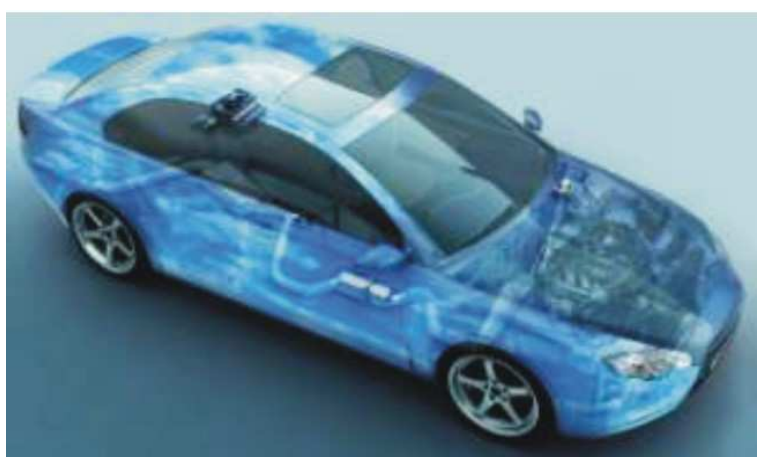

Fig. 2. Car with AdBlue system

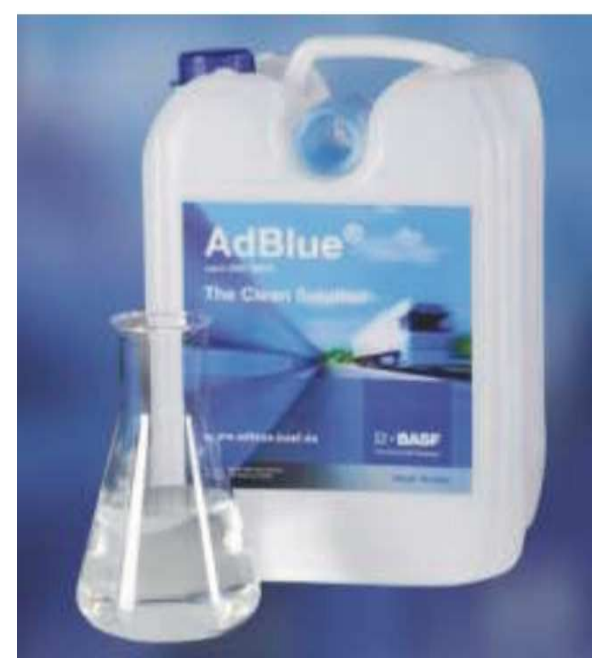

Fig. 3 AdBlue urea solution

In a urea injection system (SCR) ammonia is used to reduce nitrogen oxides (NOx).

In free stage, ammonia $\left(\mathrm{NH}_{3}\right)$ is toxic. For this reason, needs to use a water-based solution of urea (CO $\left(\mathrm{NH}_{2}\right)$ 2), the content of urea was about $32.5 \%$.

This solution is chemically stable, the freezing point is $-11^{\circ} \mathrm{C}$. Trade Name in Europe, this is AdBlue urea solution (Fig. 3). 
Urea $\mathrm{CO}\left(\mathrm{NH}_{2}\right) 2$ are obtained by industrial methods by combining carbon dioxide $\left(\mathrm{CO}_{2}\right)$ and ammonia $\left(\mathrm{NH}_{3}\right)$ at elevated temperatures and high pressures $\left(150^{\circ} \mathrm{C}, 50\right.$ bar). The resulting substance, the urea is solid, in the form of colourless crystals, soluble in water $\left(\mathrm{H}_{2} \mathrm{O}\right)$ (Petrescu and Petrescu, 2003).

Urea injection system is relatively complex and involves additional costs relatively high.

This system includes a urea tank, pump power supply system, the electronic control module (Computer) and the catalyst injector.

Additionally the system may also be provided with a nitrogen oxide sensor after the catalyst, the conversion rate of the catalyst measured (Fig. 4).

Urea tank is fitted with a level sensor to alert the driver of the need to supply urea. Also, due to the freezing temperature of the solution AdBlue (approx. $-11^{\circ} \mathrm{C}$ ) tank is provided with a resistance heater. Order resistance heating is done by the electronic control module based on information received from the temperature sensor in the tank (Fig. 5).

Bosch sells by car manufacturers complete systems Denoxtronic called AdBlue injection.

Electronic Control Module (DCU) communicate via the CAN bus with the rest of the car computer (injection, ABS/ESP, BCM, etc.).

Depending on the heat engine operating point and based on information received from sensors, electronic control module (DCU) controls the injection of AdBlue into the exhaust system (Fig. 6-8).

Using ammonia $\left(\mathrm{NH}_{3}\right)$ as a reducing agent, SCR systems substantially reduce nitrous oxides in the exhaust gases. In general, a diesel engine to reach the Euro 6 emission limits, contains the following after treatment systems have exhaust:

- oxidation catalyst (reducing $\mathrm{CO}, \mathrm{HC}, \mathrm{NO}, \mathrm{NO}$ conversion)

- particulate filter (PM reduction)

- Catalytic Reduction (SCR NO, $\mathrm{NO}_{2}$ )

- oxidation catalyst ammonia $\left(\mathrm{NH}_{3}\right.$ waste reduction) No time in this study to detail solutions of cars with hydrogen or electricity

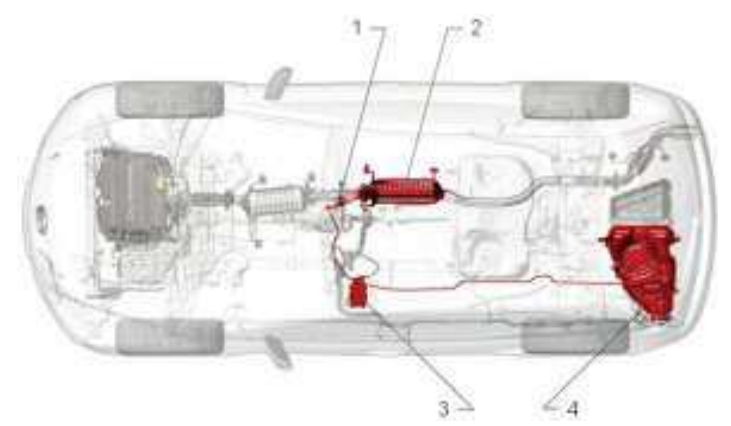

Fig. 4. Urea injection system; 1. urea injector; 2. SCR catalyst; 3. electronic control module (computer); 4. tank urea

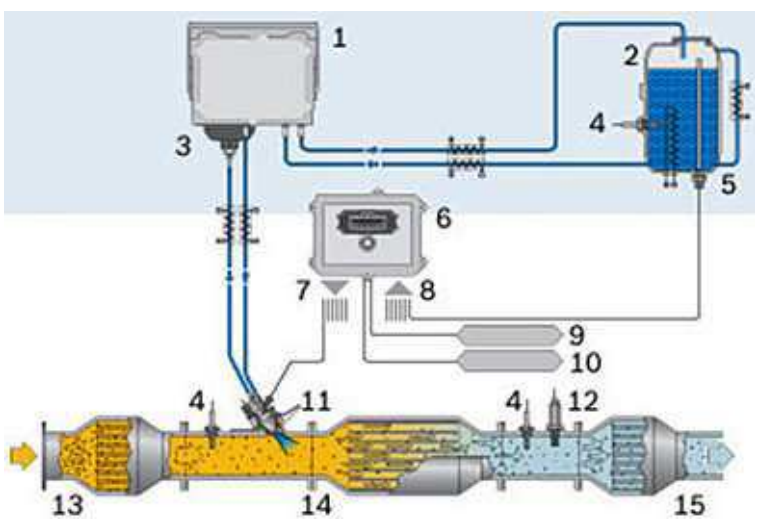

Fig. 5. Denoxtronic - treatment system for NOx emissions by injecting AdBlue; 1. supply system (pump AdBlue); 2. AdBlue tank; 3. filter; 4. exhaust gas temperature sensor; 5. AdBlue level sensor; 6. electronic control module (DCU); 7. outputs electronic control module (injector control, activation resistance heating, etc.); 8. Entries electronic control module (temperature sensors, level AdBlue exhaust gas temperature sensors, sensor NOx, etc.); 9. CAN communication protocol; 10. CAN diagnostic protocol; 11. AdBlue injector; 12. The NOx sensor; 13. The oxidation catalyst (DOC); 14. NOx reduction catalyst $(\mathrm{SCR}) ; 15$. The oxidation catalyst (ammonia neutralization)

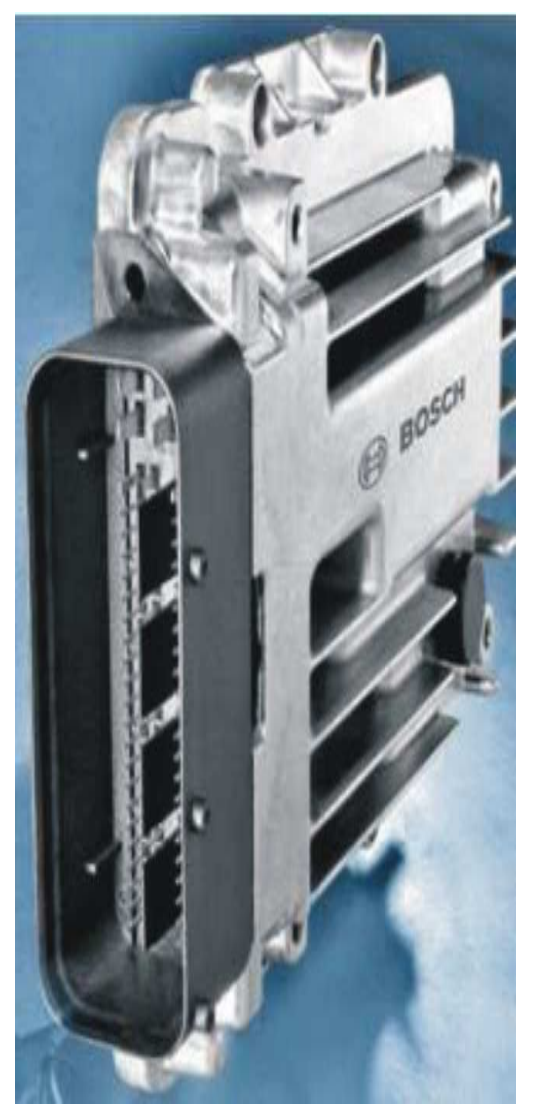

Fig. 6. AdBlue injection electronic control module (DCU) 


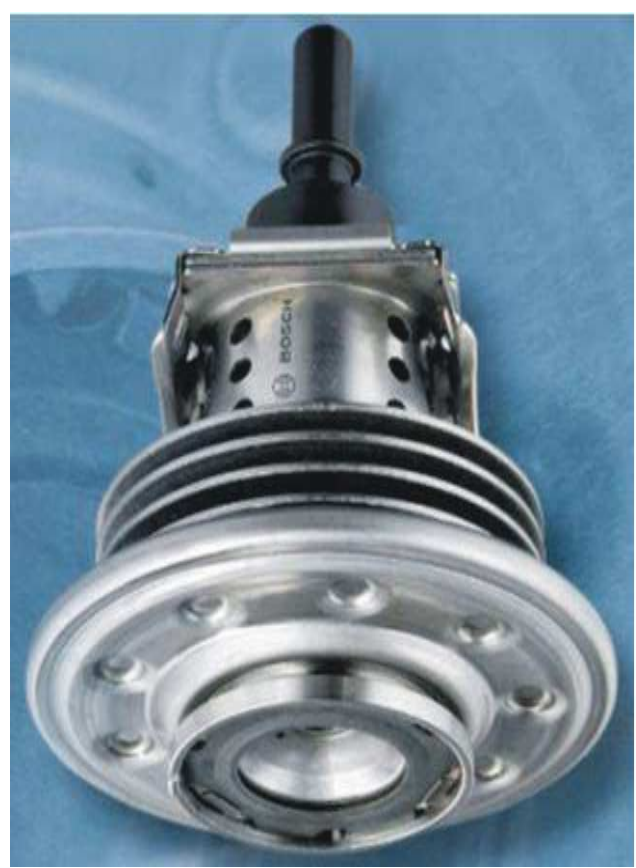

Fig. 7. AdBlue injector

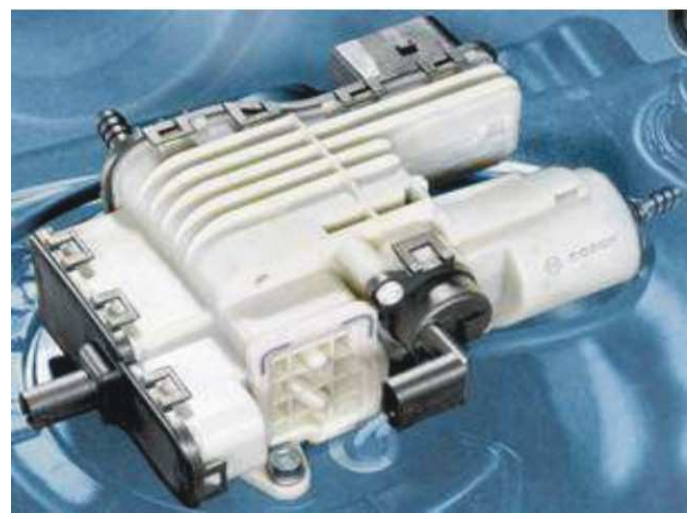

Fig. 8. AdBlue supply system (pump, filter)

\section{Rail Systems}

Trains have changed perhaps more than any other vehicle. Today are only used the freight trains pretty fastest, mostly containers and passenger trains of different speeds and qualities.

Alstom company developed especially French TGV fast trains, able to protect wagons and travelers in the event of a derailment (Fig. 9). The wagons have a special construction, simple, being fastened together through resistant bogies, that they take all the bumps and bruises (shocks) instead of the wagons.

Another solution quick, simple, cheap, effective, modern is the German solution and successfully tested already (from about 20 years) in China and Japan, the solution of Magnetic Levitation $\square$ (MagLev Fig. 10).

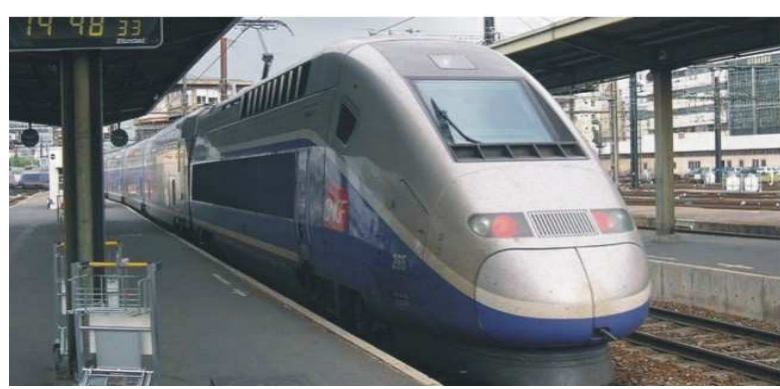

Fig. 9. A TGV train in Lyon train station

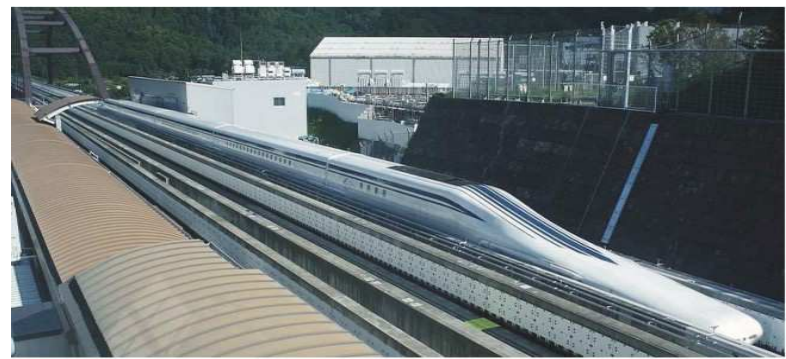

Fig. 10. A MagLev train in Japan

These trains can't theoretically cause accidents, because lacking bogies, wheels and mechanical transmissions. MagLev train easily reach 600 or 900 $\mathrm{km} / \mathrm{h}$, but is already successfully tested for 1200-1500 $\mathrm{km} / \mathrm{h}$ and in future will fly with $2000-3000 \mathrm{~km} / \mathrm{h}$.

\section{Aeronautical Systems}

After approximately 100 years of flight, humankind has made giant steps in the leading aeronautics. Boeing 787 is the new aircraft Boeing 737. This is now in the development phase (Fig. 11 and 12). The designers of this plane are hard at work to bring as many improvements for this aircraft which should be particularly effective from the point of view of the fuel consumption, through the use of composite materials in the construction of the vessel and the use of new reactors. It should enable the airlines to reduce by almost $20 \%$ fuel consumption in comparison with the old aircraft of this size. This appliance of flight is expected to compete in the world with the other types of aircraft and to win the admiration of the public. First Boeing 787 has been delivered officially by "All Nippon Airways" the September 25, 2011, to Boeing's facilities in Washington, Everett. A great ceremony was also held next day, to mark the occasion. On 27 September, the Dreamliner flew to airport Haneda. On 13 October 2011, the airline took delivery of the second 787. On 26 October 2011, the aircraft Boeing 787 carried out its first commercial flight from Narita to Hong Kong for All Nippon Airways. The aircraft was planned to enter the service with about three years before. Tickets for the 
flight have been sold in an online auction, with the highest bidder of payment that has offered $\$ 34,000$ for a place. Boeing 787 flew the first flight over long distances of commercial the 21 January 2012 from

Haneda at Frankfurt for All Nippon Airways.

On December 6, 2011, aircraft of testing ZA006 (sixth 787 built) fitted with engines General Electric GenX, flew 10.710 nautical miles $(19.830 \mathrm{~km})$ nonstop from Boeing Field to the International Airport Shahjalal in Dhaka, Bangladesh, establishing a newworld record the distance travelled for the aircraft in weight class 787 , which is between 440.000 pounds sterling $200,000(\mathrm{~kg})$ and 550,000 pounds sterling $250,000(\mathrm{~kg})$. This flight has exceeded the record previously by the 9,127 nautical miles $(16,903 \mathrm{~km})$, established in 2002 by an Airbus A330. Dreamliner then continued the toward the east of Dhaka to return to Boeing Field and establishing a record of the travel speed in the world without stopping the $42 \mathrm{~h}, 27 \mathrm{~min}$. At the end of the year 2011, Boeing has begun a tour of the world 787 in order to promote the plane of the line. He visited cities in China, Africa, the Middle East, Europe, United States of America and others. Nine out of ten passengers have said that the aircraft it has exceeded their expectations and a quarter of them have stated that they will leave their old companies to go toward the definitive Boeing 787. The air quality and the pressure in the cab have exceeded expectations for nine out of ten passengers and $92 \%$ of the passengers have reported that the atmosphere of the cab has been as good, or even better than they had expected. Four out of ten passengers have said that the cab space of passengers was greater than they had expected (Fig. 13). Finally, the large windows have exceeded and they expectations of $90 \%$ of passengers. Were polled 800 passengers who have offered 787 from Tokyo to Frankfurt. Qatar Airways has launched its first 787 from Farnborough in July 2012. The airline received officially in the aircraft for the month of August 2012.

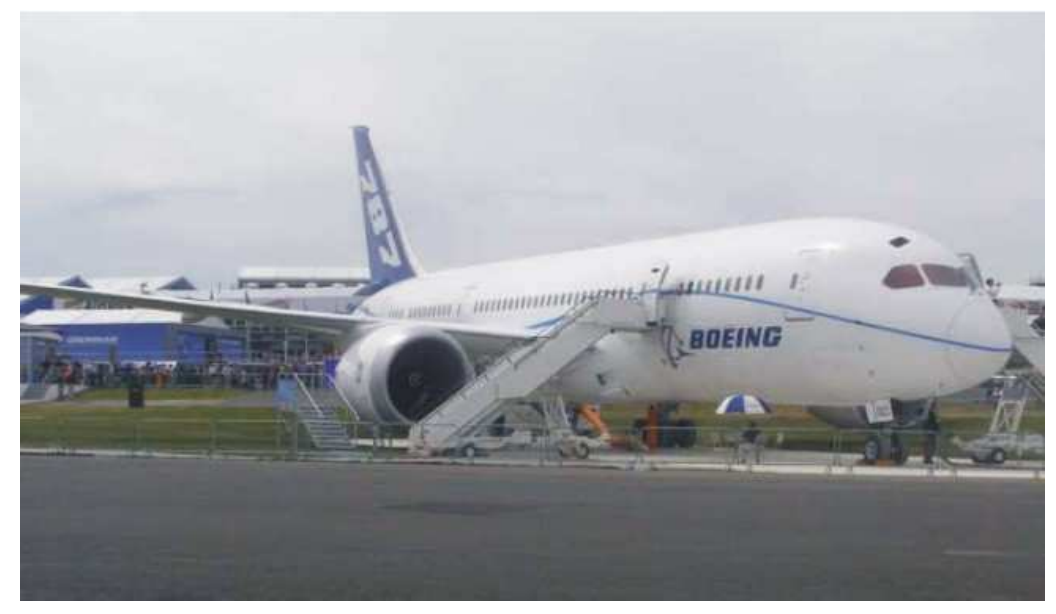

Fig. 11. The new aircraft Boeing 737

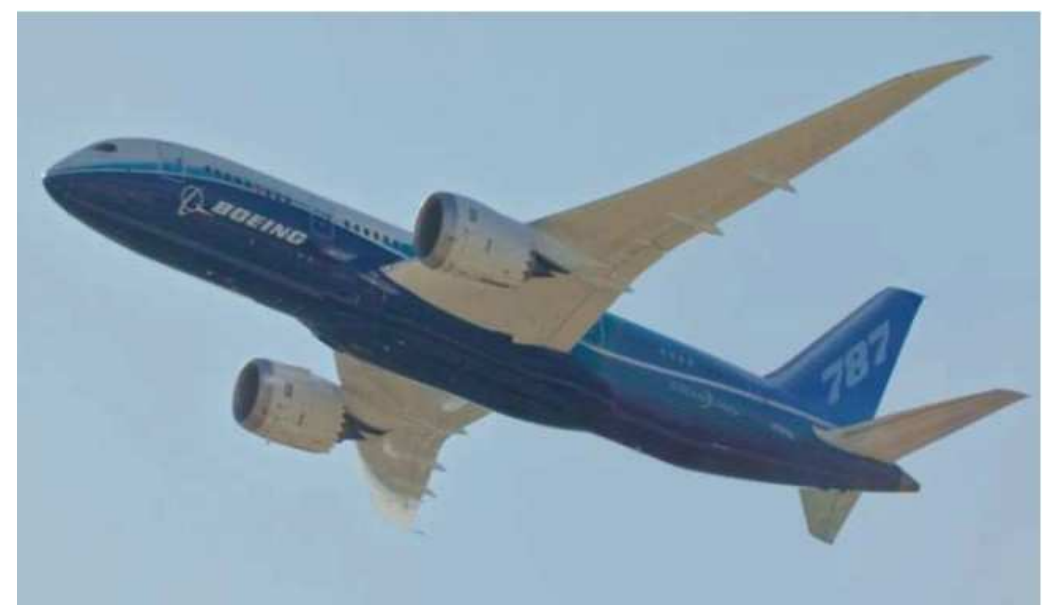

Fig. 12. The new aircraft Boeing 737 in flight 


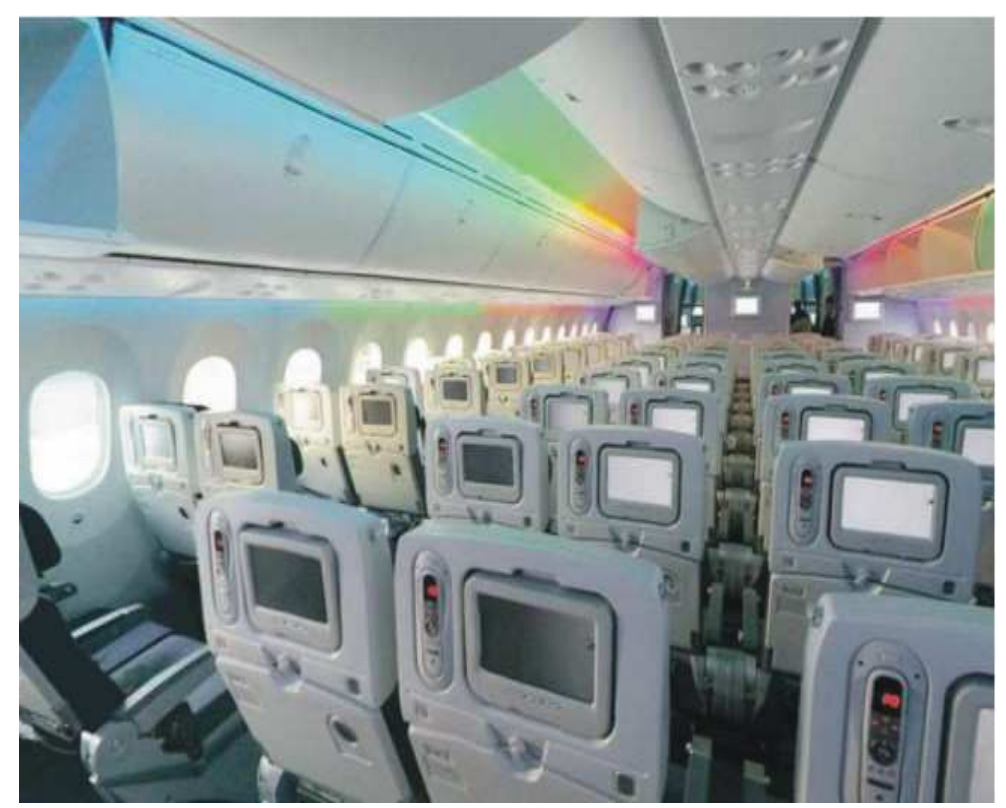

Fig. 13. Passengers' cab at a Boeing 787

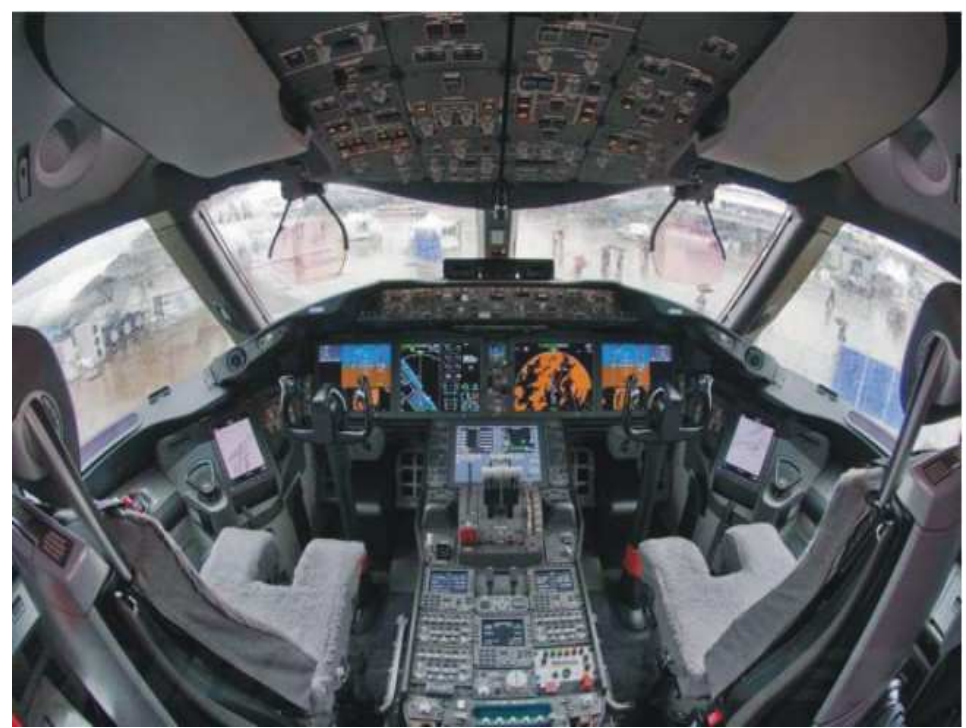

Fig. 14. Pilots' cab at a Boeing 787

The external features include wingtips and raked of engine nacelles with borders for noise reduction. The longer the radius of the aircraft 787 may cover from 8000 up to 8,500 nautical miles $(15,000$ up to $15.700 \mathrm{~km})$, sufficient to cover the Los Angeles to Bangkok or New York for routes from Hong Kong. She has a speed in full travel of the cruise Mach 0,85 (561 mph, in 903 kilometers per hour at altitudes typical of the cruise line). Among the 787 systems of the flight, the contribution of the most famous efficiency is the new electrical architecture, which replaces conventional systems hydraulic and pneumatic, with air and hydraulic energy, by new systems of compressors are electrically actuated and pumps, thus eliminating entirely the schemes to problems 8th hydraulic and pneumatic of some subsystems (e.g., starters of engines or brakes). Another new system is a system of protection against the wing icing (i.e., frost) where uses are heating electro-thermal wing tabs instead of warm air bleeding, as has been used in the traditional manner. A system of improved active burst, similar to the system used on B2 bombardier, enhances the quality of walking during turbulence. The cab of the pilots of a Boing 787 (Fig. 14) has features of flight LCD display with multiple 
functions, all these using technology GUI industrial standard widget set of tools (Navigation interfaces of the display of the system for users' systems/Arinc 661). Cab 787 aircraft includes two displays head-up (Huds) as a standard feature. The same as other aircraft Boeing 787 will use a yoke in place of some-sticks. The future integration of anticipatory action in the infra-red in the HUD of thermal detection so that the pilots can "see" in clouds is taken into account. Even the famous airplanes Lockheed Martin Orion have taken from Boeing 787 all these systems, state-of-theart with a cockpit of glass derived from 787 and systems of the pilot, Honeywell International (Petrescu and Petrescu, 2011; 2012; 2013a; 2013b; 2013c; Petrescu, 2016; Petrescu et al., 2017a; 2017b; 2017c; 2017d; 2017e; 2017f; 2017g; 2017h; 2017i).

The only aircraft able to match the performance of a huge Boeing 787 is Airbus A380 (Fig. 15 and 16).

Apart from quality aircraft and transport, transport engineering and traffic regulation deals aircraft, flight scheduling, routes, airports, terminals, boarding and disembarkation of passengers and their baggage control and air traffic management. As you see, there are a lot of problems.

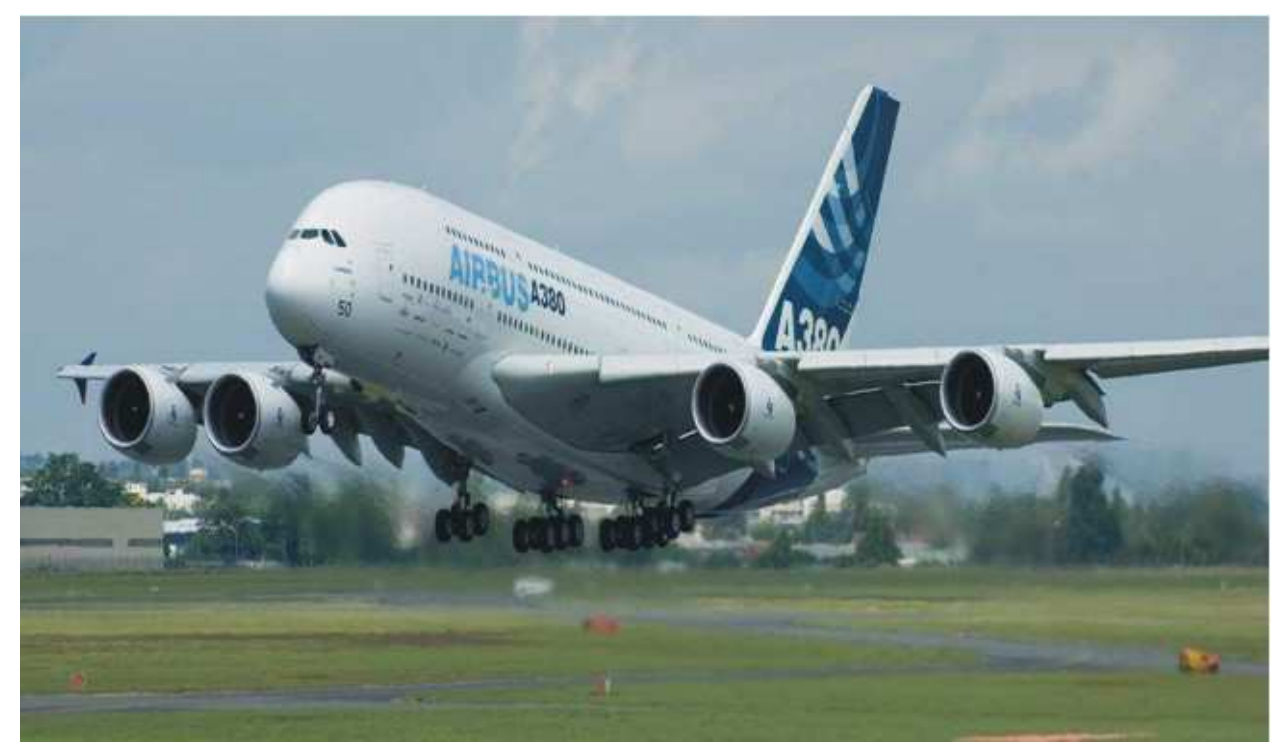

Fig. 15. Airbus A380

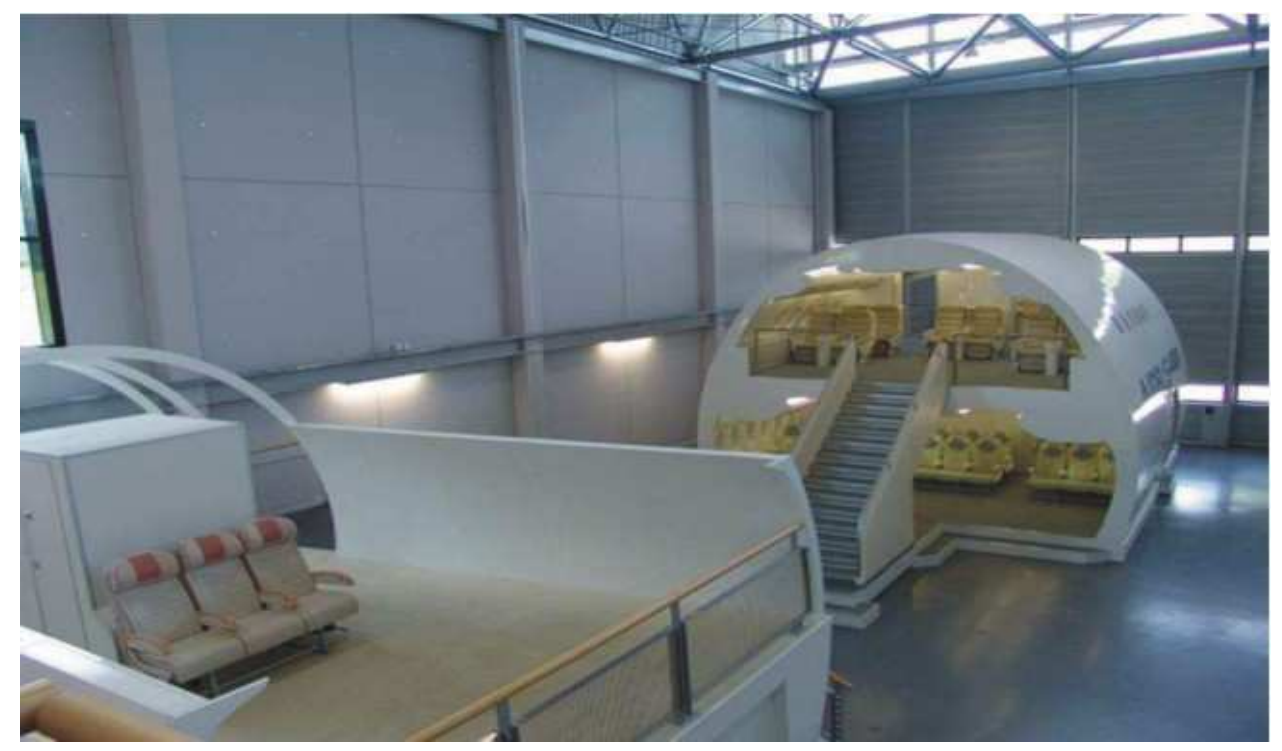

Fig. 16 Airbus A380 in the factory 


\section{Transport of River and Maritime Hydrodynamics and Hydraulics}

The bases of fluid mechanics (hydrodynamics and hydraulics) are important with emphasis on the energy aspect, because the engineer must most often consider flows of non-isothermal fluids. Attempts have been made to clearly present the unity of concepts which concern all fluids and whose application generally relates solely to Newtonian mono-phasic fluids.

It is essential that the engineer always keep a critical eye on the hypotheses he introduces to facilitate his calculations or on the adequacy of the formula he employs in the particular case studied; The mechanics of fluids is an area where common sense can easily deceive. We must verify the validity of a hypothesis after having obtained the solution of the problem. A common example is the determination of the flow rate of a flow that is assumed to be turbulent to begin calculations; is it really? It is necessary to ensure, by the value of the Reynolds number, that the expediency of a laminar flow is excluded.

Software that is currently marketed solves the complex technical problem equations. Their design required the respect of the theoretical bases but introduced hypotheses and empirical formulas which have their limits of validity as well as the algorithms of resolution. The use of software requires the vigilance of the non-specialist engineer of fluid mechanics. This type of software is composed to provide benchmarks and simple calculation means allowing a quick evaluation to be valid to the first order.

As opposed to the solid, the liquid or gaseous fluid is easily deformable, without it being necessary to apply great stresses to its contour. The same material can pass from the state of the solid to that of the fluid (liquid then gas) under the effect of a temperature increase at constant pressure. In mechanics of deformable media, the fluid is described by an equation of behaviour that links the local stress to the rate (or speed) of deformation, whereas for the solid intervenes a relation between stress and deformation.

The behavioural relationship is mechanical. The description of the fluid also relates to thermodynamics through the equation of state, which expresses the relationship between density, pressure and temperature in the case of thermodynamic equilibrium.

To solve a problem of fluid mechanics, mass balance, momentum and energy equations are used.

The dynamics of fluids are established on the basis of the general theorems of the mechanics of material systems and the principles of thermodynamics. The analysis can be carried out at two different scales: One, relating to a macroscopic volume of fluid, called a control volume, is suitable for engineers seeking a global and approximate solution; The other analysis, which applies to an elementary volume of fluid within the control volume, leads to partial differential equations which can be generally integrated only by the use of numerical methods. The fields of the characteristic quantities of the fluid are then known in the control volume. The first interesting approach refers to the case of permanent flows.

Since Newton, Fourier, Ampere and many others, the question of the dimensions of the entities of the physical world has been fiercely debated: Does an entity have an intrinsic dimension? We know today that it is the nature of the entity that is intrinsic and that the dimension is variable according to the system of units chosen in reference to describe it. The international convention has fixed the international system of SI units, but in order to deal with similarity, this obligation must occasionally be dispensed with.

Similarity became very important when, in 1883, O. Reynolds experimentally found that a flow of water in a pipe changes structure when a dimensionless grouping of physical quantities, called a Reynolds number, assumes a certain value critical and at the beginning of the 20th century, the German School of Fluid Mechanics developed the representation of phenomena through dimensionless groupings.

An important problem is the study of "LAMINATING FLOWS AND TURBULENT FLOWS" (Reynolds number, from Wikipedia).

A few months after Reynolds discovered the sudden appearance of a change in the structure of the permanent flow in a tube when the velocity was increased, Couette made a similar observation for a fluid contained between two concentric cylinders, a constant speed and thereafter, the observation of the existence of two regimes was made on any circumstance of flow. The moderate speed is laminar while the other is turbulent, to mark the fact of a mixing of the fluid which is superimposed on the main movement. This can be observed very well on the meteorological scale: A weathervane marking a direction that is more or less constant over time, with oscillations around the mean (Couette flow, from Wikipedia).

The wind intensity itself varies over time with an average constant speed modulus. Finally, brewing is itself observable by the complex movement of the clouds. In the absence of variable conditions imposed on the fluid, the turbulent regime is an average steady state.

Another problem is "FORCES EXERCISED ON OBSTACLES BY A MOVING FLUID".

It is equivalent to consider an immovable obstacle placed in a fluid in motion or the moving obstacle in a fluid at rest, as long as the law of relative motion is respected. This equivalence is exploited in aerodynamic wind tunnels which are studied so that there is no untoward distortion due to the presence of the walls. We limit ourselves to the case of obstacles animated by movements of uniform translation of velocity $\mathrm{V}$ in a 
motionless fluid which fills a very wide domain with respect to the largest dimension of the obstacle.

About "MONODIMENSIONAL PERMANENT FLOWS IN INTERNAL MECHANICS" it's important to see if a fluid which extends at a great distance from the obstacle on which a dynamic boundary layer develops, has the behaviour of which conditions the aerodynamic qualities of the obstacle, considering only the flow of a fluid inside.

\section{Infrastructure, Environment and Transport by Water}

Issues of design of infrastructures and facilities:

Principles of Implementation and Development of Maritime Ports.

Waterways.

Logistics Dimensioning of a Site.

Wave protection works.

Commercial and fishing ports - Furnishing and equipment.

Port Management and Operations.

Customs Logistics.

Industrial ecology in port territories - International practices.

Infrastructure Asset Management.

Water transport.

Managing international logistics - Transport and customs.

Customs, a key element in the facilitation of international trade - International.

Customs instruments.

Freight Economics - Transport Process.

Freight Economics - Transport System.

Incoterms 2000 - A tool for international trade.

Transport occupations.

Goods transport.

Quality transport.

The transport of dangerous goods.

Transport and sustainable development.

Intermodal transport.

Maritime transport.

Inland waterway transport.

Environmental issues and risks.

Institutional landscape of water actors.

Coastal protection.

Legal and regulatory protection of aquatic environments.

\section{Aerospace}

\section{Lockheed SR-71 Blackbird}

Lockheed SR-71 "Blackbird" has been designed with long-range, very advanced, designed as Mach 3 strategic aircraft of recognition. It has been developed as a draft of the aircraft for the recognition Lockheed A-12 in 1960 by Lockheed Skunk Works. Clarence Kelly Johnson has been responsible for many of the concepts of innovative design (Fig. 17).

During the tasks of recognition SR-71 which operates at speeds and altitudes very large for allows you to counterattack the threats arising in real time. In the case in which it has been detected a launching the missile ground-to-air, he has simply been designed to accelerate and superseded missiles in order to be able to destroy it in real time, before re-entering the terrestrial atmosphere (Fig. 17).

\section{Martin Marietta X-24A}

X-24 (Fig. 18) was one of a group of lifting equipment controlled by NASA Flight Research Center (now Dryden Flight Research Center) in a common program with the United States Air Force at Edwards Air Force Base in California, since 1963 until 1975. The bodies of the lifting equipment have been used to demonstrate the ability of the pilots to maneuver and safely land vehicles without fenders designed for flying back toward Earth from space and to be landed as an airplane at a predetermined situs.

\section{Lockheed Martin X-33}

Lockheed Martin X-33 (Fig. 19) was a, sub-scale of technology demonstrator suborbital without pilot also developed Space Shuttle in 1990, within the framework of the program financed by the government US Space launch initiatives.

X-33 was a demonstrator for the spaceship VentureStar orbital sander, which was planned to be a last generation, exploited commercial vehicles of reusable launch.

X-33 has tested a number of technologies which NASA has considered that are necessary for launching missiles with a single step up on the orbit with reusable vehicles (SSTO RLVs), technologies like: Metal systems the thermal protection, tanks composite cryogenic receptacles fuel for hydrogen liquid, aerospike engine, itself (without pilot) for the control of the flight, quick flight time for transmission via the optimized operations and streamlined body the lifting eye.

\section{Orbital Sciences $X-34$}

The Orbital Sciences X-34 (Fig. 20) was intended as a low-cost test bed to demonstrate "key technologies" integrable to the Reusable Launch Vehicle program.

\section{$N A S A X-43$}

$\mathrm{X}-43$ (Fig. 21) is a plane experimental hipersonic without pilot with multiple variations to the planned scale designed to test the various aspects of the flight hipersonic. 


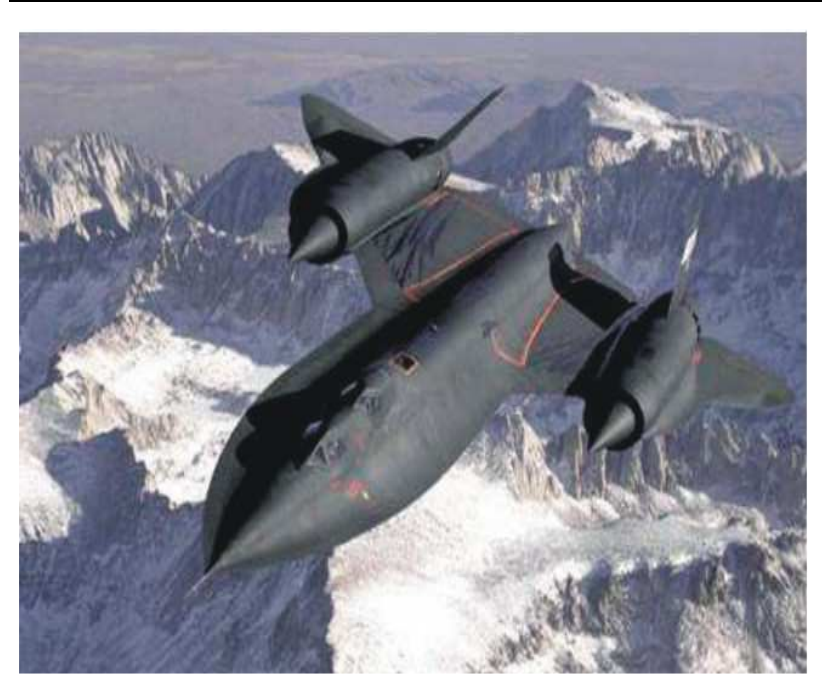

Fig. 17. Lockheed SR-71 "Blackbird"

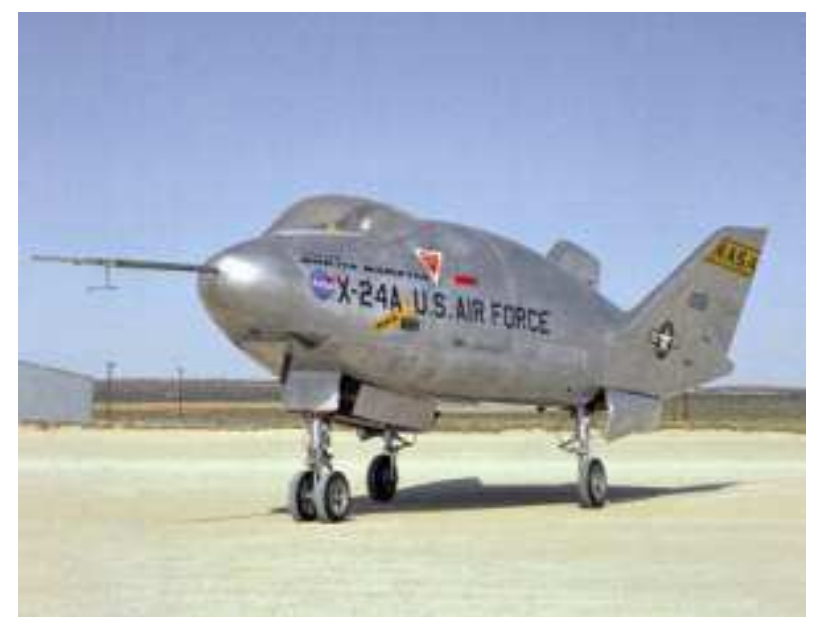

Fig. 18. Martin Marietta X-24A

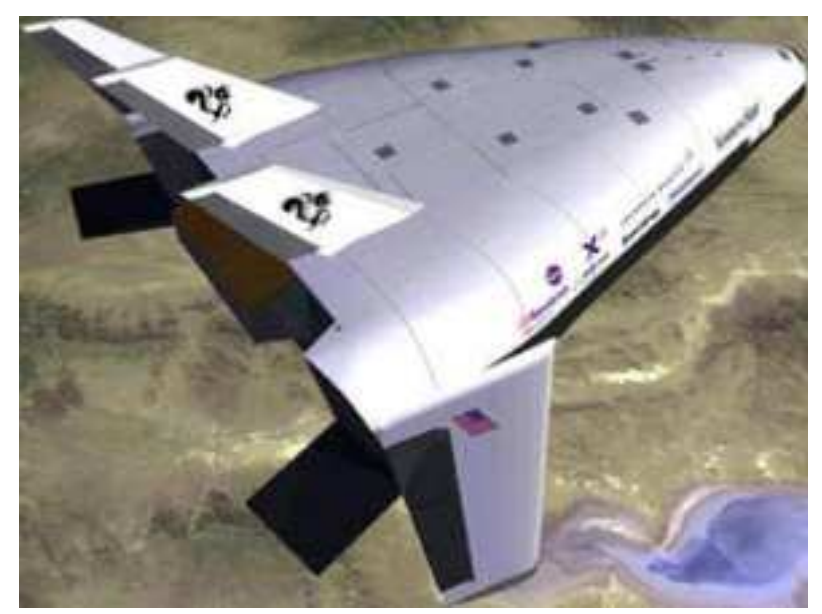

Fig. 19 Lockheed Martin X-33

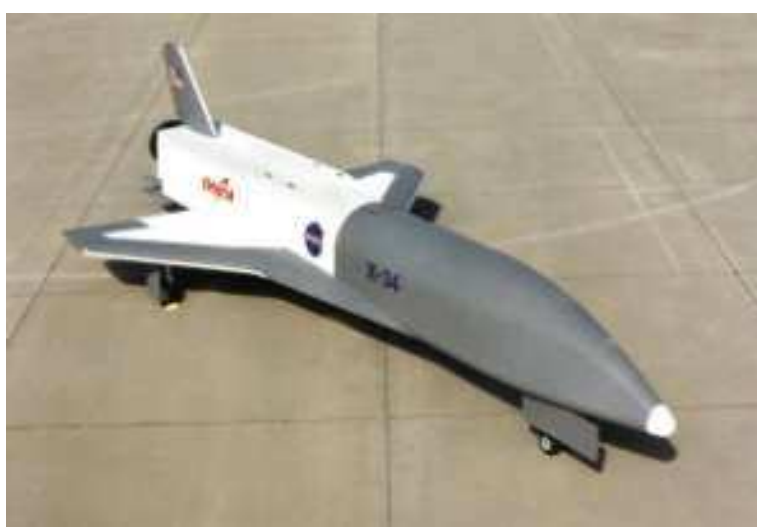

Fig. 20. The orbital sciences X-34

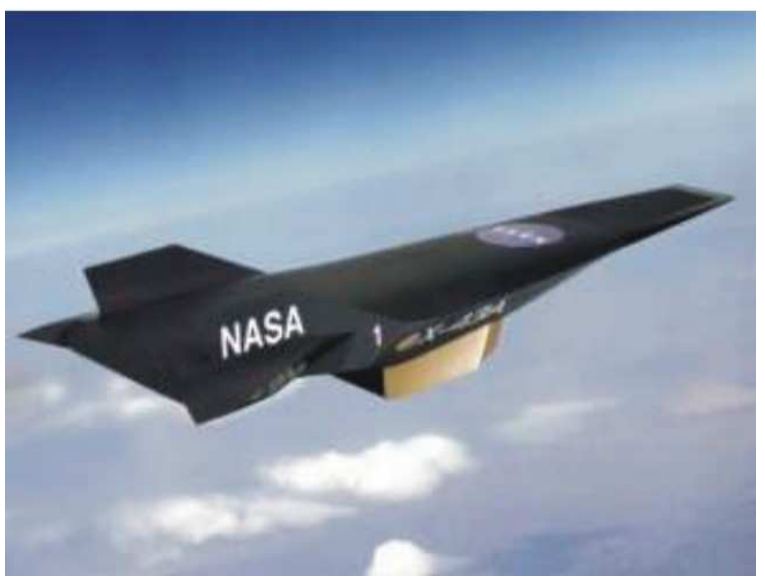

Fig. 21. NASA X-43

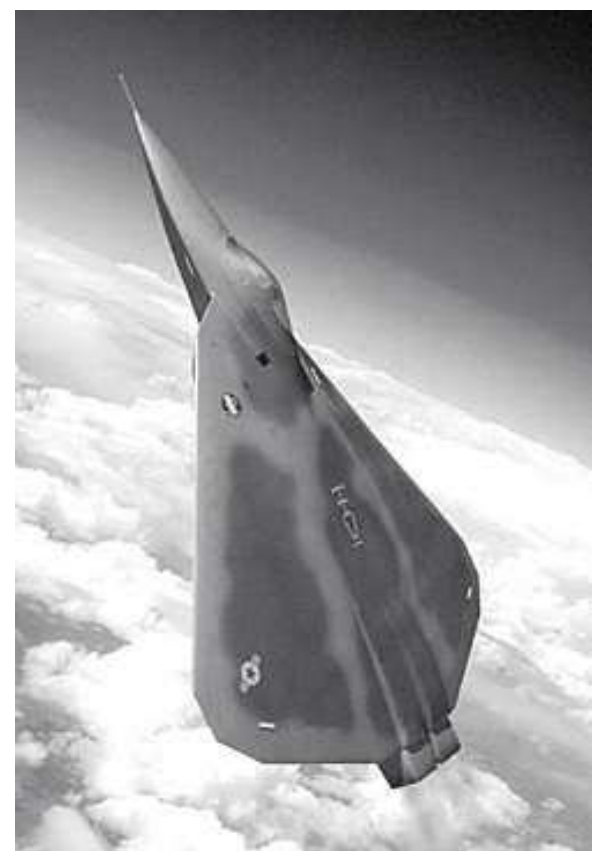

Fig. 22. Lockheed Martin X-44 MANTA 
It has been a part of the hyper-X of NASA. He has established multiple box office records the speed for the aircraft propelled with jet.

\section{Lockheed Martin X-44 MANTA}

Lockheed Martin X-44 Multi-Axa Airplanes-Tail (MANTA; Fig. 22) has been a design of aircraft the conceptual Lockheed Martin, which was studied by NASA and the US Air Force.

It has been designed to test the feasibility of the yaw rate and handling attitude which is based simply on 3D the tractive force vectorized. The design of the aircraft was derived from F-22 Raptor.

\section{DARPA Falcon Project}

The DARPA Falcon Project (Force Application and Launch from Continental United States; Fig. 23) is a two-part joint project between the Defense Advanced Research Projects Agency (DARPA) and the United States Air Force (USAF) and is part of Prompt Global Strike (Petrescu and Petrescu, 2011; 2012; 2013a; 2013b; 2013c; Petrescu, 2016).

A part of the program aims to develop a reusable ship, quick, war, armament Hipersonic System (HWS), now reintitulata Hipersonic Cruise Vehicle (VHC) and the other part of the program is for the development of a system of launching able to accelerate a VHC at speeds of cruise and the launch of small satellites orbit the earth.

This program two parties, was announced in 2003 and continued in 2006.

\section{MIT's D "Double Bubble"}

MIT's D "double bubble" (Fig. 24) series design concept, is based on a modified "tube-and-wing" structure that has a very wide fuselage to provide extra lift; the aircraft would be used for domestic flights to carry 180 passengers in a coach cabin roomier than that of a Boeing 737-800.

\section{Box Wing Design}

Lockheed Martin had a completely different approach to.

Engineers have proposed a design of the wing in which a front wing mounted on the belly of bottom of the aircraft is matched to the tips toward a wing the stern mounted on the top of the aircraft (Fig. 25).

The company has studied the concept of the wing for three decades, but it has been the need of waiting until the have developed composite materials easy for its construction.

\section{A NASA Design Concepts}

NASA has explored a variety of options for quieting boom, starting with design concepts and moves through the tests in the aerodynamic tunnel to the tests of the flight of new technologies (Fig. 26).

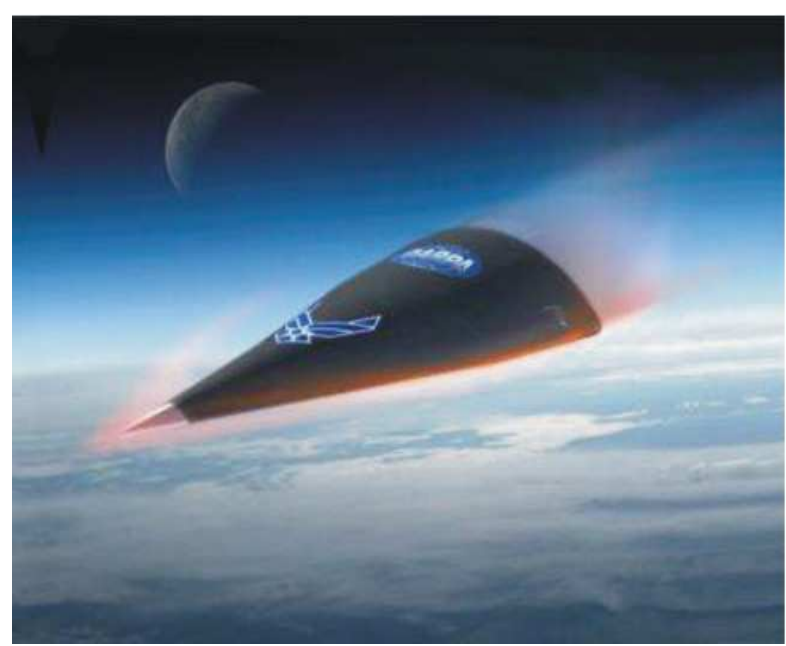

Fig. 23. The DARPA Falcon Project

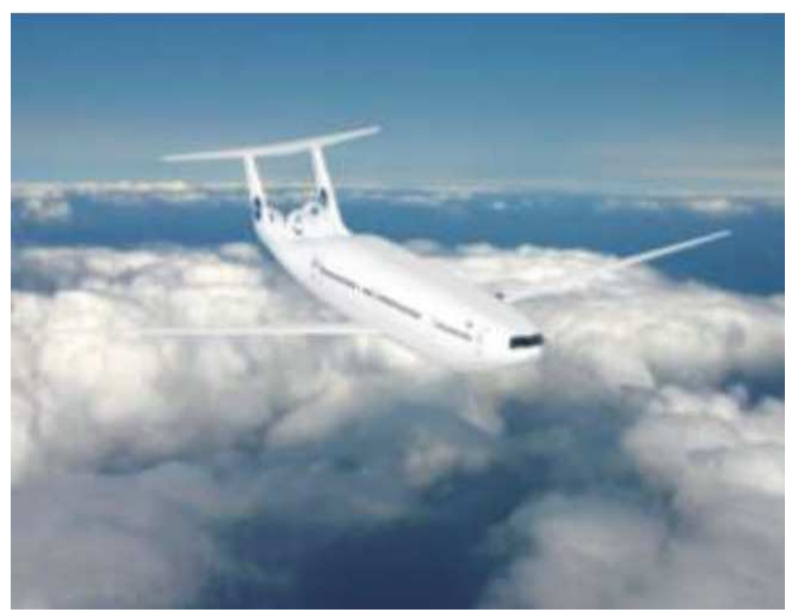

Fig. 24. MIT's D "double bubble"

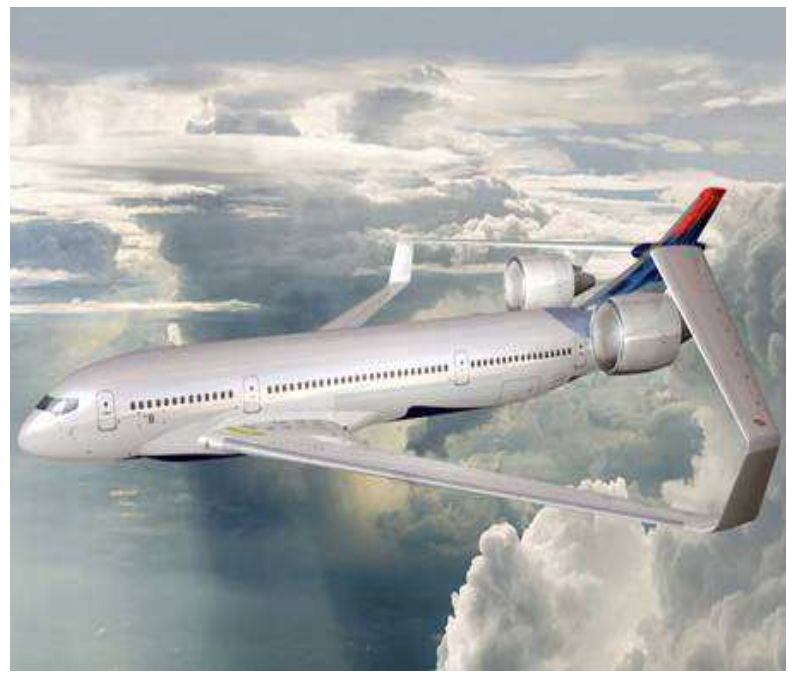

Fig. 25. A Lockheed Martin design 


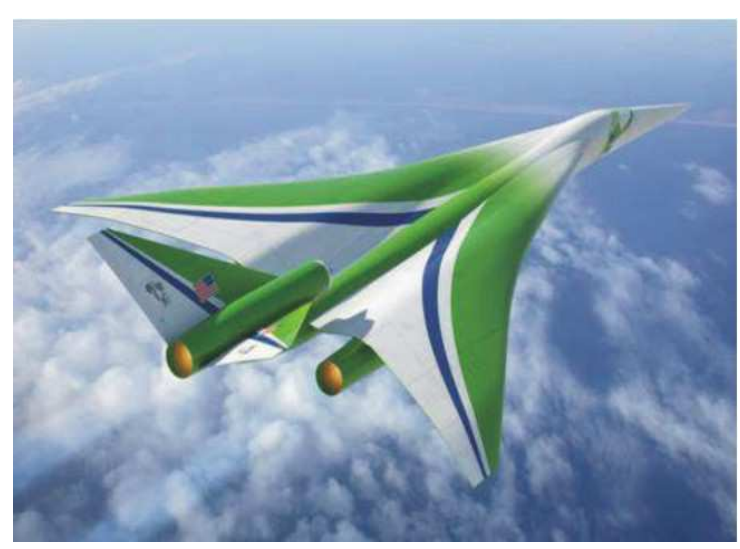

Fig. 26. A NASA design concept

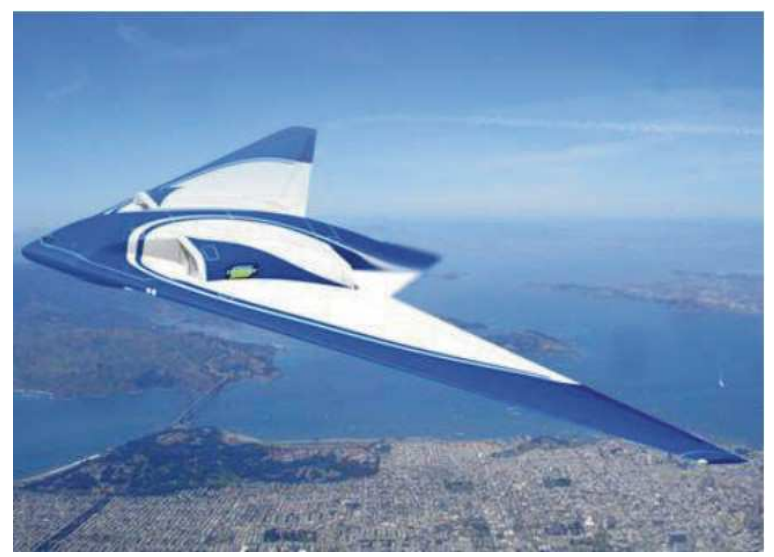

Fig. 27. Flying wing a regular sight

This playback of a possible future for the public transport supersonic presents a vehicle that is configured to reduce the signature of the shock wave sonic and also to reduce resistance to travel.

\section{Flying Wing a Regular Sight}

This type of design, produced by the Northrop Grumman, most probably transporting goods in the first and then also carry passengers (Fig. 27).

This design is among those presented to NASA at the end of the year 2011 by the companies that have made the studies financed from NASA in aircraft which it would be able to enter into service in 2025 .

\section{Green Supersonic Machine}

This future aircraft design concept for supersonic flight over land comes from the team led by the Lockheed Martin Corporation.

This concept (Fig. 28) is one of two designs presented in April 2010 to the NASA Aeronautics Research Mission Directorate for its NASA Research Announcement-funded studies into advanced supersonic cruise aircraft that could enter service in the 2030-2035 timeframe.

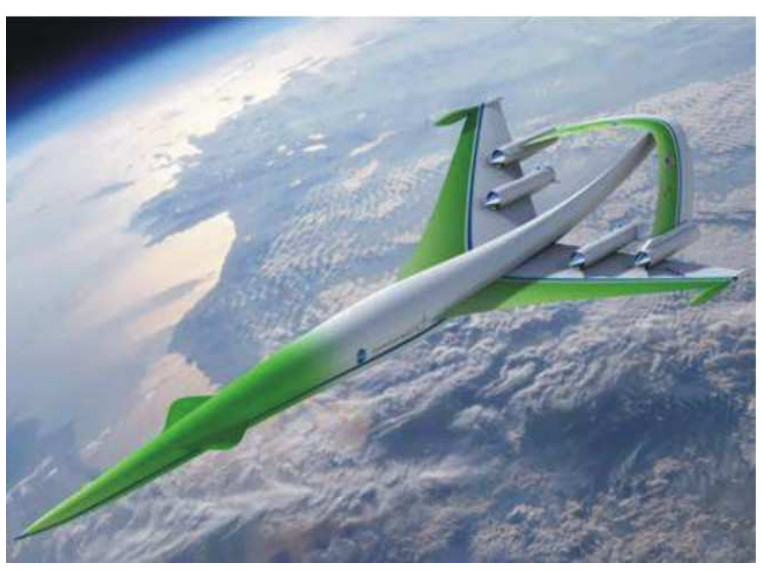

Fig. 28. Green supersonic machine

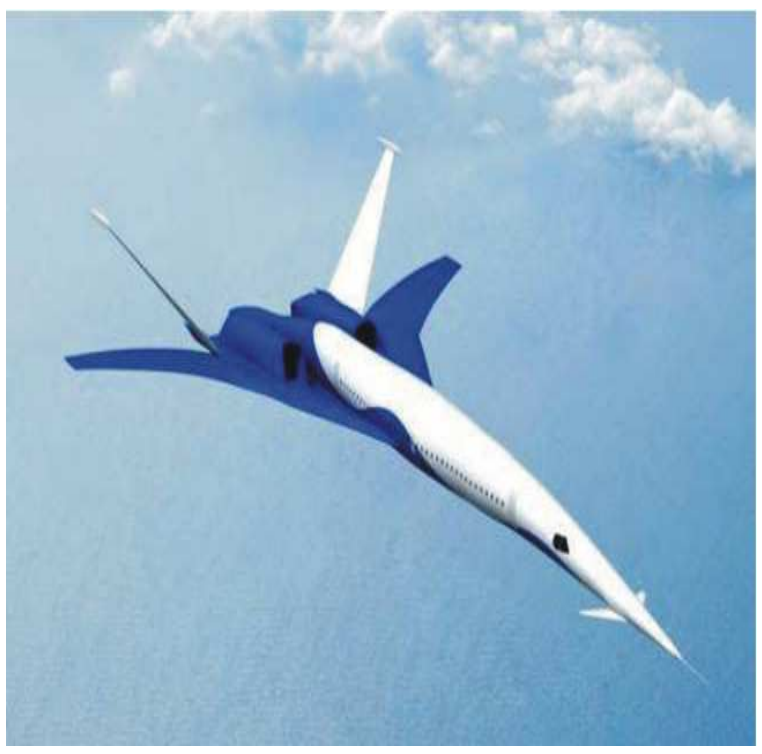

Fig. 29. The "Icon-II" future aircraft design concept

\section{The "Icon-II" Future Aircraft Design Concept}

The "Icon-II" future aircraft design concept for supersonic flight over land comes from the team led by The Boeing Company (Fig. 29).

A design that allows for the attainment of the objectives of the reduction of the fuel and the silencer burn from the airport, is also performs the Great discounts of the noise levels sonic boom, to meet the target level needed to supersonic flight on land as possible (Petrescu and Petrescu, 2011; 2012; 2013a; 2013b; 2013c; Petrescu, 2016).

This concept is one of the two models shown in the month of April 2010 to the direction in which the mission of NASA research aeronautics for his studies financed from the NASA Announcement of research in the aircraft advanced cruise united that could come into service within the period 2030-2035. 


\section{SKYLON into Orbit}

Reaction Engines has announced that is has successfully tested the key pre-cooler component of its revolutionary SABRE engine crucial to the development of its SKYLON spaceplane (Petrescu and Petrescu, 2011; 2012; 2013a; 2013b; 2013c; Petrescu, 2016).

The company claims that craft equipped with SABRE engines will be able to fly to any destination on Earth in under 4 hours, or travel directly into space (Fig. 30).

\section{Special Vehicles}

There are a lot of categories of special ground such as: Agricultural tractors, tractors with plug, goods lifts, cranes, concrete or machines, firemen, save, ground heavy, ground military, electro vehicles machines, the intervention agency cables, Special backed up from the railway, trailers etc.

And in this field transport engineering has got a lot of things to do.

Of the category of special vehicles have developed and unconventional vehicles, such as: Hovercrafts (Fig. 31), catamarans (Fig. 32), submarines (Fig. 33), metro rails (subway; Fig. 34) etc.

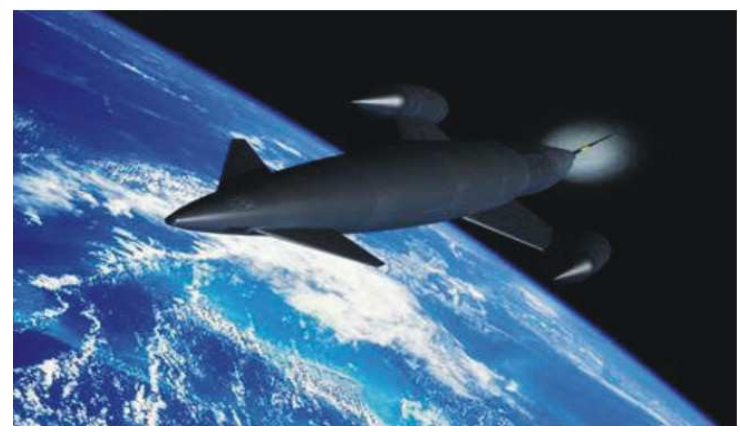

Fig. 30. SABRE engine crucial to the development of its SKYLON space plane

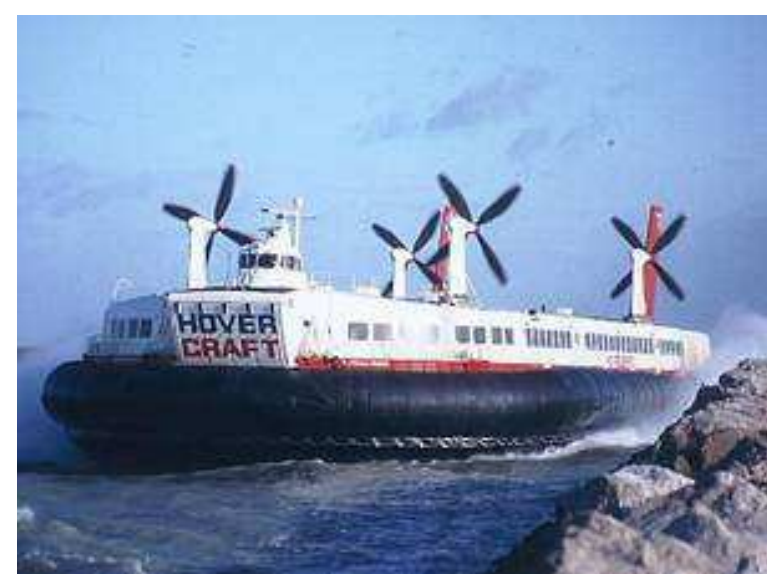

Fig. 31. A hovercraft

\section{Special Transportations (Pipes)}

The transport by pipelines are very old. In ancient Rome there were already water pipes as well as pipes for transporting sewage and wastewater.

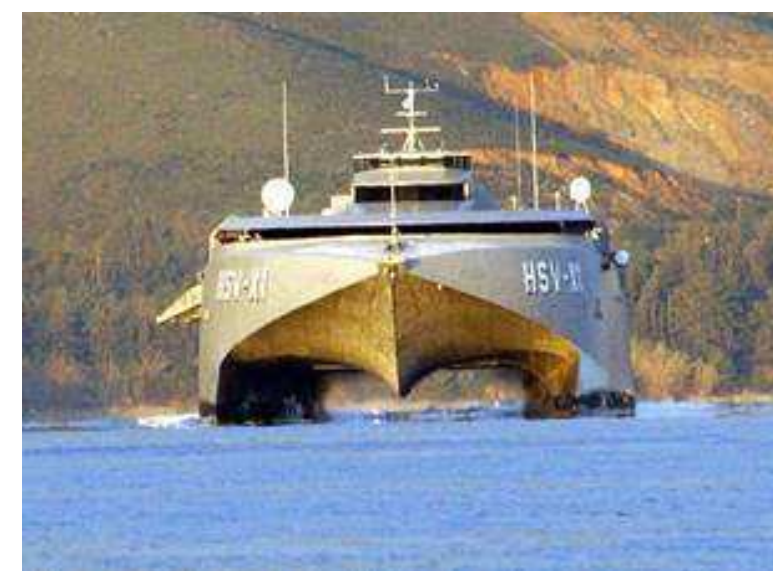

Fig. 32. A catamaran

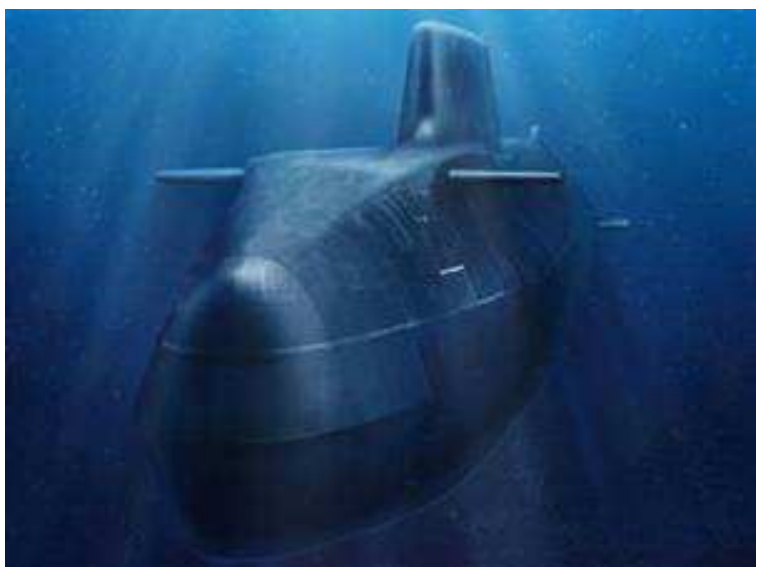

Fig. 33. A submarine

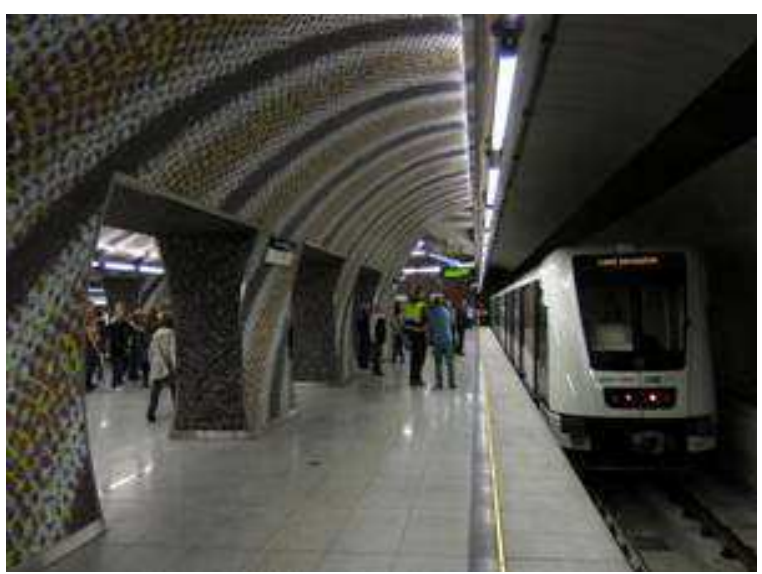

Fig. 34. A subway 


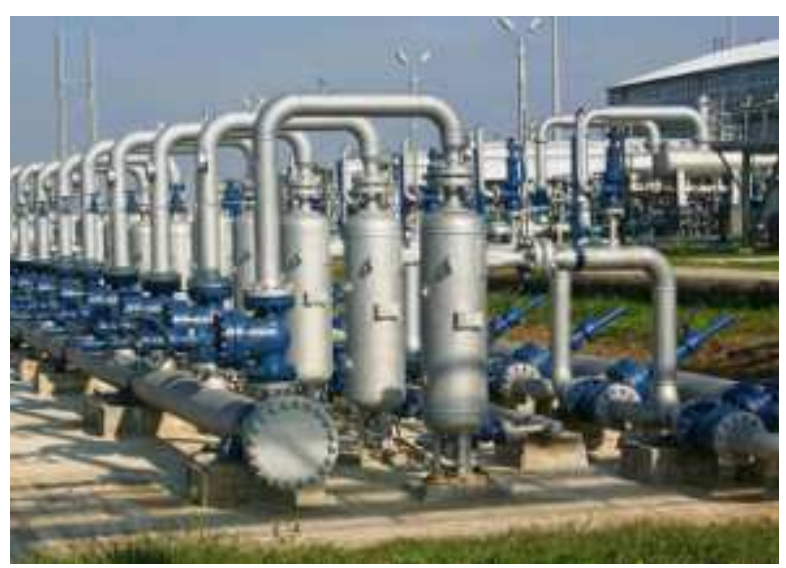

Fig. 35. Through the pipes shall be transported today all sorts of liquid chemical

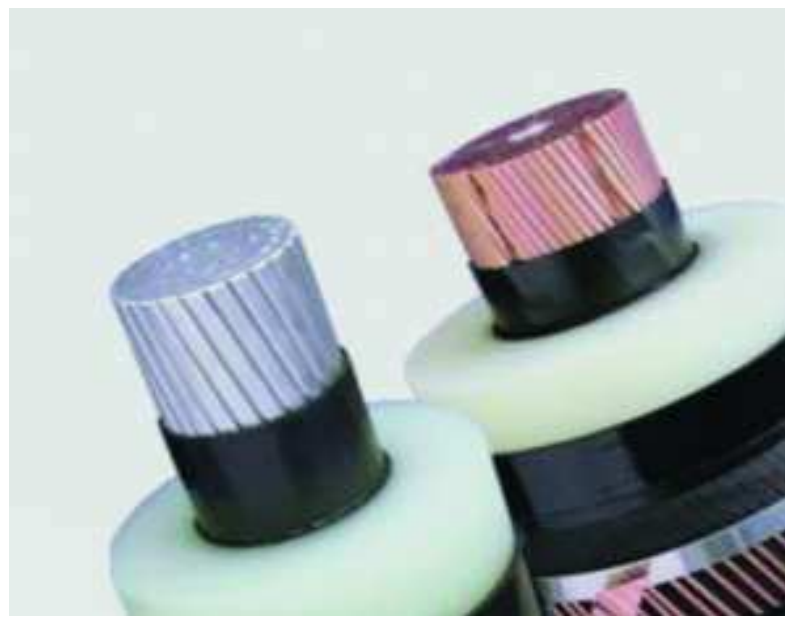

Fig. 36. Cables of very high voltage with insulation of crosslinked polyethylene (XLPE) capable to transport currents of the high and very high voltage, with a rated voltage of up to $500 \mathrm{kV}$

The modern world through pipelines now carry any type of fluid on short and medium distances and are transported over longer distances drinking water, oil and natural gas or newer ones, of shale. Through the pipes shall be transported today all sorts of liquid chemical (Fig. 35).

Engineering problems raised by pipeline transport are many, but the biggest benefit for them has been their use of composite materials in new pipelines, which led to a longer pipelines life of about 100 years instead of 25 years.

Today we have and very many cables of transport; carrying electric current, or information on the different distances. Today it may produce cables of very high voltage with insulation of cross linked polyethylene (XLPE) capable transport currents of the high and very high voltage, with a rated voltage of up to $500 \mathrm{kV}$ (Fig. 36).

\section{Conclusion}

The shipments were absolutely necessary at all times, but still have polluted and damaged the environment.

The technique of transport or the engineering of transport is the application of the principles of technology and scientific findings to the planning, design check, operation and plan management for any mode of transport, in order to ensure that the conditions of safety, efficiency, quick, comfortable and convenient, economic and environmentally compatible movement of persons and goods (transport). It is a sub discipline for civil engineering.

The importance of the transport engineering in the framework of the profession of civil engineering can be evaluated by the number of divisions of the American Society of Civil Engineers (ASCE), which are directly related to the transport.

There are six such divisions (Aerospace; Air Transport, motorways, pipes, watercourses, port, of coastal and ocean and urban transport), which represents one third of the total 18 technical divisions of the ASCE (1987).

Humanity is struggling between technological tests of deployment of new types of mild transport for the environment and the need to maintain still in the operation the machines already polluting products in large quantity, cheaper, more convenient economically, that customers have already been accustomed.

Transport is at the heart of major cross-cutting issues that are inseparable from issues related to the development and sustainable management of the mobility of goods and people. The automotive sector must meet several challenges to reduce the emission of particulate and gaseous pollutants while limiting the increase in the cost of vehicles. The development of "clean" or "sustainable" vehicles requires the integration of innovative technologies to meet all these requirements. Those all problems need to be addressed by the discipline named Transportation (Transport) Engineering, in view of the constantly improving the quality of transport carried out.

The energy challenge facing humankind today in the energy field is to reduce $\mathrm{CO}_{2}$ emissions and, gradually, to substitute fossil fuels with other sources of energy that do not emit carbon dioxide $\left(\mathrm{CO}_{2}\right)$.

To meet this challenge, it is necessary to save energy, to use more efficient devices and to use carbon-free (renewable and nuclear) energy sources on a large scale.

The main uses of energy are, in descending order of consumption, the production of thermal energy, transport and electricity.

Electricity is produced worldwide, mostly with coal, but this energy vector can nevertheless be generated virtually from all sources of energy, including carbon-free sources. Transport, on the other hand, depends almost 
entirely on oil. As far as heat or cold is concerned, fossil fuels could in the future be replaced in the future.

Energy storage is the weak point of the energy sector and major progress remains to be made in this area, which is particularly essential for exploiting intermittent energy sources.

Habitat and transportation consume much of the world's energy. Significant gains in energy are possible in the habitat.

On the other hand, for transportation, the problem is more difficult. Hydrogen, an energy vector on which many bet on short-term transport, will be especially useful for the manufacture of liquid fuels and petrochemicals. It should also be noted that the amount of energy that a source can deliver is not the only important parameter and that in some industrial applications it is sometimes also necessary to have high power levels. Continuous high powers that many renewable sources are incapable provide.

In the field of freight transport, heavy goods vehicles are currently the central link, since they transport the vast majority of goods that meet our needs, thus making our economy live.

Despite lower energy performance than the heavy modes of railways and inland waterways, these vehicles have become established thanks to their flexibility, speed and, ultimately, their profitability.

As a result, the contribution of trucks to greenhouse gas and pollutant emissions is high, with, as a corollary, a dangerous link between our economy and a single resource: Oil.

Given the constraints, the expected progress must be on both: Pollutant emissions and fuel consumption, associated GHG emissions and energy diversification, while maintaining favorable economic equations.

There are a lot of categories of special ground such as: Agricultural tractors, tractors with plug, goods lifts, cranes, concrete or machines, firemen, save, ground heavy, ground military, electro vehicles machines, the intervention agency cables, Special backed up from the railway, trailers etc.

And in this field transport engineering has got a lot of things to do.

\section{Acknowledgment}

The work was appreciated by teams of professors from the departments of automobiles from several universities in Romania and Italy. This text was acknowledged and appreciated by Associate Professor Aniello Riccio SECONDA UNIVERSITA' DEGLI STUDI DI NAPOLI Italy, Dr. (Ms.) Shweta Agarwala Senior Research Scientist at Singapore Center for 3D Printing Nanyang Technological University Singapore, whom we thanks and in this way.

\section{Author's Contributions}

All the authors contributed equally to prepare, develop and carry out this manuscript.

\section{Ethics}

This article is original. Authors declare that are not ethical issues that may arise after the publication of this manuscript.

\section{References}

Aversa, R., R.V. Petrescu, F.I.T. Petrescu and A. Apicella, 2016a. Biomimetic and evolutionary design driven innovation in sustainable products development. Am. J. Eng. Applied Sci., 9: 1027-1036. DOI: 10.3844/ajeassp.2016.1027.1036

Aversa, R., F. Tamburrino, R.V. Petrescu, F.I.T. Petrescu and M. Artur et al., 2016b. Biomechanically inspired shape memory effect machines driven by muscle like acting NiTi alloys. Am. J. Applied Sci., 13: 1264-1271 DOI: 10.3844/ajassp.2016.1264.1271

Aversa, R., V. Perrotta, R.V. Petrescu, C. Misiano and F.I.T. Petrescu et al., 2016c. From structural colors to super-hydrophobicity and achromatic transparent protective coatings: Ion plating plasma assisted $\mathrm{TiO} 2$ and $\mathrm{SiO} 2$ Nano-film deposition. Am. J. Eng. Applied Sci., 9: 1037-1045.

DOI: 10.3844 /ajeassp.2016.1037.1045

Barrett, G.W. and E.P. Odum, 2000. The twenty-first century: The world at carrying capacity. Bio. Sci., 50: 363-368. DOI: $10.1641 / 0006-$ 3568(2000)050[0363:TTFCTW]2.3.CO;2

Cauvin, C., 1994. Accessibilité de système et accessibilité locale. Flux, 10: 39-48.

Couette flow, from Wikipedia, the free encyclopedia.https://en.wikipedia.org/wiki/Couette flow

Dupuy, G., 1991. L'urbanisme des réseaux, théories et méthodes.

Feldman, B., 2008. The hybrid automobile and the Atkinson Cycle. Physics Teacher, 46: 420-420. DOI: $10.1119 / 1.2981291$

Gallez, C., J.P. Orfeuil and R. Polacchini, 1997. L'évolution de la mobilité quotidienne: Croissance ou réduction des disparités? Recherche Transports Sécurité, 56: 27-42.

Genre-Grandpierre, C., 2007. Qualité de l'offre et usage $\mathrm{du}$ transport public en milieu urbain. Euro. J. Geography, Document. DOI : 10.4000/cybergeo.6736

Genre-Grandpierre, C., 2000, Forme et fonctionnement des réseaux de transport: Approche fractale et réflexions sur l'aménagement des villes. $\mathrm{PhD}$ Thesis, Université de Franche-Comté. 
Gutiérrez, J., A. Monzòn and J.M. Pinero, 1998. Accessibility, network efficiency and transport infrastructure planning. Environ. Plann. A, 30: 1337-1350.

Leet, J.A., S. Simescu, K. Froelund, L.G. Dodge and C.E. Roberts Jr, 2004. Emissions solutions for 2007 and 2010 heavy-duty diesel engines. Proceeding of the SAE World Congress and Exhibition, (WCE' 04), Detroit, Michigan, pp: 1-11.

Madre, J.L. and J. Maffre, 1997. La mobilité des résidants français: Panorama général et evolution. Recherche Trans. Sécurité, 56: 9-26.

Mahalingam, S. and B.R. Ramesh Bapu, 2013. Experimental and emission analysis of rubber seed oil and jatropha oil blends with diesel in compression ignition engine. IREME J., 7: 955-959.

Naima, K. and A. Liazid, 2013. Numerical investigation on combustion behaviors of direct-injection spark ignition engine fueled with CNG-hydrogen blends. IREME J., 7: 652-663.

Petrescu, R.V.V., R. Aversa, A. Apicella, F. Berto and S. Li et al., 2016a. Ecosphere protection through green energy. Am. J. Applied Sci., 13: 1027-1032. DOI: 10.3844 /ajassp.2016.1027.1032

Petrescu, F.I.T., A. Apicella, R.V.V. Petrescu, S.P. Kozaitis and R.B. Bucinell et al., 2016b. Environmental protection through nuclear energy. Am. J. Applied Sci., 13: 941-946.

Petrescu, F.I.T. and J.K. Calautit, 2016. About nano fusion and dynamic fusion. Am. J. Applied Sci., 13: 261-266. DOI: 10.3844/ajassp.2016.261.266

Petrescu, R.V. and F.I. Petrescu, 2013a. Lockheed Martin. 1st Edn., Books On Demand, ISBN-13: 978-3848260539, pp: 114.

Petrescu, R.V. and F.I. Petrescu, 2013b. Northrop. 1st Edn., CreateSpace, ISBN-13: 978-1480145658, pp: 96.

Petrescu, R.V. and F.I. Petrescu 2013c. The Aviation History or New Aircraft I Color. 1st Edn., CreateSpace, ISBN-13: 978-1482777062, pp: 292.

Petrescu, F.I. and R.V. Petrescu, 2012. New Aircraft II. 1st Edn., Books On Demand, ISBN-13: 978-3848208920, pp: 138.

Petrescu, FI and R.V. Petrescu, 2011. Memories about Flight. 1st Edn., CreateSpace, ISBN-13: 978-1467930321, pp: 652.

Petrescu, F.I. and R.V. Petrescu, 2003 Câteva elemente privind îmbunătățirea designului mecanismului motor. Proceedings of 8th National Symposium on GTD, (NSG' 03), Brasov, pp: 353-358.
Petrescu, R.V., 2012. Calitatea Transporturilor. 1st Edn., CreateSpace, ISBN-13: 978-1479391660, pp: 124.

Petrescu, F.I., 2016. Valorificarea Traditiei Ingineresti Romanesti-I. 1st Edn., CreateSpace, ISBN-13: 978-1537177984, pp: 152.

Petrescu, R.V., R. Aversa, B. Akash, R. Bucinell and J. Corchado et al., 2017a. Modern propulsions for aerospace-a review. J. Aircraft Spacecraft Technol.

Petrescu, R.V., R. Aversa, B. Akash, R. Bucinell and J. Corchado et al., 2017b. Modern propulsions for aerospace-part II. J. Aircraft Spacecraft Technol.

Petrescu, R.V., R. Aversa, B. Akash, R. Bucinell and J. Corchado et al., 2017c. History of aviation-a short review. J. Aircraft Spacecraft Technol.

Petrescu, R.V., R. Aversa, B. Akash, R. Bucinell and J. Corchado et al., 2017d. Lockheed martin-a short review. J. Aircraft Spacecraft Technol.

Petrescu, R.V., R. Aversa, B. Akash, J. Corchado and F. Berto et al., 2017e. Our universe. J. Aircraft Spacecraft Technol.

Petrescu, R.V., R. Aversa, B. Akash, J. Corchado and F. Berto et al., 2017f. What is a UFO? J. Aircraft Spacecraft Technol.

Petrescu, R.V., R. Aversa, B. Akash, J. Corchado and F. Berto et al., 2017g. About bell helicopter FCX001 concept aircraft-a short review. J. Aircraft Spacecraft Technol.

Petrescu, R.V., R. Aversa, B. Akash, J. Corchado and F. Berto et al., 2017h. Home at airbus, J. Aircraft Spacecraft Technol.

Petrescu, R.V., R. Aversa, B. Akash, J. Corchado and F. Berto et al., 2017i. Airlander. J. Aircraft Spacecraft Technol.

Reynolds number, from Wikipedia, the free encyclopedia.

https://en.wikipedia.org/wiki/Reynolds_number

Ronney, P.D., M. Shoda, S.T. Waida and E.J. Durbin, 1994. Throttleless premixed-charge engines: Concept and experiment. J. Automobile Eng., 208: 13-24.

Sethusundaram, P.P., K.P. Arulshri and K. Mylsamy, 2013. Biodiesel blend, fuel properties and its emission characteristics sterculia oil in diesel engine. IREME, 7: 925-929.

Thevenin, T., 2002. Quand l'information géographique se met au service des transports publics urbains, une approche spatio-temporelle appliquée à l'agglomération bisontine. Thèse de doctorat, Université de Franche-Comté. 